\title{
Assessment of Histopathological Damages in African Catfish (Clarias garienpinus) as Influenced by Nittol Detergent Aquatic Pollution in Nigeria
}

\author{
E. A. Ivon ${ }^{1}$, N. A. Etangetuk ${ }^{1}$, G. M. Ubi ${ }^{2^{*}}$, C. O. Anyanwu ${ }^{1}$, A. N. Nkang ${ }^{1}$ \\ and A. P. Ekanem ${ }^{3}$ \\ ${ }^{1}$ Department of Science Laboratory Technology, Faculty of Biological Sciences, University of Calabar, \\ Nigeria. \\ ${ }^{2}$ Department of Genetics and Biotechnology, Faculty of Biological Sciences, University of Calabar, \\ Nigeria. \\ ${ }^{3}$ Department of Fisheries and Aquaculture, Institute of Oceanography, University of Calabar, Nigeria.
}

Authors' contributions

This work was carried out in collaboration among all authors. Author EAl designed the study. Authors EAI, APE and GMU performed the statistical analysis. Authors EAI, COA and APE wrote the protocol. Author EAl wrote the first draft of the manuscript. Authors EAI, APE and GMU managed the analyses of the study. Authors EAI and COA managed the literature searches. All authors read and approved the final manuscript.

Article Information

DOI: $10.9734 / A R R B / 2020 / v 35 i 430206$

Editor(s):

(1) Prof. Tunira Bhadauria, Kanpur University, India.

Reviewers:

(1) Mohamed El. Sayed Megahed, National Institute of Oceanography and Fisheries (NIOF), Egypt. (2) Jesiel Mamedes Silva, Universidade Federal de Mato Grosso do Sul, Brazil. Complete Peer review History: http://www.sdiarticle4.com/review-history/55171

Original Research Article

Received 10 January 2020

Accepted 14 March 2020

Published 19 May 2020

\section{ABSTRACT}

Toxicity of Nittol detergent on the histopathology of the African catfish (C. gariepinus) sub adult was investigated. The experiment was conducted in triplicates of four treatments. Behavioral changes in fish exposed to different concentrations of Nittol detergent ranged from erratic swimming, moribund movement, jumping and lack of balance. Similar changes were not observed in the control throughout the experiment. Nittol detergent is composed of linear Alkyl Benzene Sulphonate (LABS), sodium tripolyphosphate (STPP), sodium carbonate, sodium sulphate, sodium perborate and sodium silicate (perfume) as active ingredients. The fish were exposed to concentrations 1.0 $\mathrm{g} / \mathrm{L}, 2.0 \mathrm{~g} / \mathrm{L}, 3.0 \mathrm{~g} / \mathrm{L}$ and $4.0 \mathrm{~g} / \mathrm{L}$. At $1.0 \mathrm{~g} / \mathrm{l}$ concentration, the mean mortality was $80 \%$ with an initial 
erratic swimming. It was observed that mean mortality increased drastically with increase in concentration of the pollutant (Nittol detergent). At concentration $3.0 \mathrm{~g} / \mathrm{L}$, total mortality was observed within 72 hours of exposure preceding moribund swimming while total mortality was observed in $4.0 \mathrm{~g} / \mathrm{L}$. The concentration at which $50 \%$ of the experimental fish were killed (LC50) was $1.9 \mathrm{~g} / \mathrm{L}$. Results from statistical analysis indicated that mortality varied $(p<0.05)$ significantly with concentrations as higher values recorded higher mortalities. However, mean values showed highest mortality (74\%) with Nittol detergent. Histopathology of the liver of fish exposed to Nittol after $96 \mathrm{hrs}$ revealed severe damage and necrosis of the liver cells when compared with the control which had a normal distribution of hepatic cells. Similarly, results from histopathology of the gills of the exposed fish to Nittol detergent revealed fusion and damages to gills lamellae when compared with the control which has normal distribution of the gills lamellae. Severe changes in the epithelia of the gill arch were also observed. Findings from histopathology of the intestine also revealed severe damages to the intestinal walls and mucosa when compared with the control. Images from the histopathology of the gills revealed severe damages to the gill lamellae by the Nittol detergent whereas the control showed a normal distribution of gills lamellae. And in the same vein, histopathology result on the effect of Nittol Detergent on the intestine of the exposed fish revealed chronic damages to the intestinal mucosa when viewed with motic electron microscope at $\times 10$ magnification. It was therefore concluded that Nittol Detergent causes significant and severe damages to $C$. gariepinus and recommended the control disposal of this detergent into aquatic bodies to reduce the negative impact on the histopathology of aquatic organisms.

Keywords: Nittol detergent; histopathological effect; African catfish; aquatic pollution.

\section{INTRODUCTION}

African catfish (Clarias gariepinus) African catfish (C. gariepinus) are sharp tooth catfish, eel-like in nature, usually dark gray or black with coloration on the back, fading to a white belly. In Africa, the catfish has been reported as being second in size only to the Vundu of the Zambesian waters [1]. It has an average adult length of $1.0-1.5 \mathrm{~m}$. It reaches maximum length of $1.7 \mathrm{~m}$ and can weigh up to $60 \mathrm{~kg}$. These fish have slender bodies, flat bony heads, notably flatter in the genus Silirus, and broad terminate mouths with four pairs of barbels. They also have large accessory breathing organs composed of modified gill arches and only the pectoral fins have spines. African catfish is a nocturnal fish like many other catfish. It feeds on both living and dead animal matter. Because of its wide mouth, it is able to swallow relatively large prey whole. It is able to crawl on dry ground to escape drying pools and it is also able to survive in shallow mud for long periods of time in between raining seasons [1,2]. It spawns around inundated areas of river, lakes and streams mostly at nights [3]. One of the reasons for the choice of this genus of fish for this research work is because it has been found to be a biomarker in the aquatic environment [4]. Other reasons for this choice of this fish includes its' hardiness and ability to tolerate adverse water quality conditions, its ability to grows fast and feed on large variety of agriculture by products.
And its ability to tolerates difficult conditions in captivity [5]. Most chemicals exhibit deleterious effects on the acquatic environment if not properly handled or controlled. Industrial products beneficial to man can also pose serious threats to man and the entire environment [6]. Most of the commonly used industrial products in Calabar, Nigeria include detergents, fertilizers, kerosene and a host of others [7]. Pollution is a global menace that affects all ecological habitats. It is the introduction of foreign toxic substances capable of causing harm to man and the entire environment $[8,9]$.

Pollution occurs either on land, air or water. Man depends heavily on water for domestic, industrial and agricultural uses. Poorer water quality means water pollution $[10,11]$. No nation is completely free from the global menace of water pollution $[12,13]$. This era of globalization and industrialization has sky rocketed the rates of aquatic pollution due to the increasing volume of industrial and domestic effluents that find their way into fresh water and marine habitats, thus altering the balance of these ecosystems [14,15].

In developing countries like Nigeria, only few chemicals have been ecologically tested for safety in spite of their environmental impacts $[16,17]$. Every ocean and every continent, from the tropics to the once-pristine polar regions is contaminated $[18,19]$. The effects of these activities are often outrageous with 
corresponding immediate or later consequences to both direct and indirect dependents of these water bodies [20,21]. Strict government legislation and heavy penalties have not in any way changed these negative trends of indiscriminate disposal of chemicals into our water bodies. Detergent is one of the most toxic pollutants we have in the world today inflicting so much damages to the environment and the organisms thereon especially those in the aquatic environment [22,23].

Unrestricted municipal sewage discharge into water bodies, effluents from chemical industries and direct dumping of biodegradable and nonbiodegradable wastes are other sources of water pollution. Apparently, human and ecological disorders experienced in industrial settlements as a result of improper disposal of chemicals such as detergent effluents are alarming [24,25].

Detergents apart from altering water quality and chemistry, inflicts heavy and sometimes mortal damages to aquatic organisms and their dependents, [26,27]. However, the fish habitats are being contaminated alarmingly through a number of aquatic pollutants [28]. Detergents are widely used in both industrial and domestic premises and are mostly used in washing vehicles, clothes, carpets, cooking utensils, floors, cutleries and other dirty objects, [29]. Most pollutants including detergents find their way into water bodies through surface run offs, improper sewage discharge, direct discharge during washing and bathing in streams, rivers and other water bodies [29,30]. Detergents also posses the tendencies of unleashing poisonous effects in all types of aquatic life if found in sufficient quantities and these includes the biodegradable detergents [30,31]. Most fishes will die when detergent concentration approach 15 parts per million [32,33].

Detergent concentration as low as 5 ppm will kill fish eggs [34]. As a result of the enormous adverse effects detergents have on the aquatic environment, they are listed among the major aquatic pollutants in the world [35]. Their effects on the environment outweighs any other advantage(s). Its affordability and high efficiency in removing stains from object makes a greater number of people prefer using it in Nigeria [36]. One of the aquatic organisms often affected drastically by these chemical pollutants called detergent is the African catfish [37,38]. Phosphates are used in detergents to soften hard water and help suspend dirt in water [39].
Apart from being used for washing and removal of stubborn dirts and stains, detergents have been found to be very effective for oil spills clean up. But studies have it that the detergent often used to clean up oil spills appear more toxic to coral reefs than the oil itself [40].

Detergents are organic compounds, which have both polar and non-polar characteristics. They tend to exist at phase boundaries, where they are associated with both polar and non-polar media. Detergents are of three types: Ammonic, cationic and non-ionic. Anionic and cationic have permanent negative or positive charges attached to non-polar (hydrophobic) C-C Chains. Nonionic detergents have no such permanent charge; instead, they have a number of atoms which are weakly electropositive or electronegative. This is due to detergents with different characteristics: Phosphate detergents and surfactant detergents [41].

Detergents that contain phosphate are highly caustic and surfactant detergents are very toxic. The differences are that surfactant detergents are used to enhance the wetting, foaming, dispersing and emulsifying properties of detergents [42]. Nittol detergent was chosen for this research. Nittol detergent is composed of linear Alkyl Benzene Sulphonate (LABS), sodium tripolyphosphate (STPP), sodium carbonate, sodium sulphate, sodium perborate and sodium silicate (perfume) as active ingredients. It is a new product of less than two years in the market as at the time of commencing this research [43]. It is in view of the high patronage and usage of this highly toxic detergent that this research was tailored to unveil the histopathological damages associated with the indiscriminate pollution of aquatic environment with this chemical pollutant.

\section{MATERIALS AND METHODS}

\subsection{Study Location}

The University of Calabar is located in between the Calabar municipality and Calabar south local government areas of Cross River State, Nigeria. It is bounded to the east by the great quo river, Calabar is the capital of Cross River State, Nigeria. It is located geographically at 4057 " North 80191 0' East. Cross River State is one of the States in the Niger Delta, South South Region of Nigeria. The State shares a maritime boundary with Cameroon in the east, Akwa Ibom State in the South, Abia and Ebonyi States in the 
West and Benue State in the North. It is geographically located at $50451 \mathrm{~N}, 80301 \mathrm{E}$ 150751N, 8.50E, Holzloener, (2002). The State according to National Population Commission (NPC) (2005) has a population of 3.2 million people with a land mass of $20,156 \mathrm{~km}^{2}(7,782$ sqm).

The temperature in Calabar ranges from 21.050 to 33.150 Celsius. It is often at its maximum within the months of January to April. Rainfall in Calabar is not stable and consistent as it rains through the year. It rains more between the months of April and November with the peak between May and October. Calabar has an average annual precipitation of $2718 \mathrm{~mm}$ [44].

Calabar is situated in the tropical rain forest with mangroves and swamps in some areas. It is described as 'clean and green State'. Most of the original vegetation in the study area has been replaced as a result of agriculture, industrial and building activities [44].

Activities in the rural areas are mainly agriculture and petty trading, the urban areas are characterized by heavy commercial activities, industrialization and tertiary education. Fish farming is also one of the major human activities in both rural and urban areas of the study location [44].

\subsection{The Fish Farm}

The University of Calabar Fish Farm is located about 1 kilometer away from the research laboratory. The fish farm harbours various sizes and species of fishes ranging from fry, fingerlings sub adults and adults. This research was carried out in the Fish Pathology Laboratory of the Faculty of Oceanography, University of Calabar. Collection of samples and gathering of materials was preceded by a thorough reconnaissance survey.

\subsection{Sources of the Pollutants}

The Nittol detergent was purchased from Victory stores, Satellite town, Calabar in Cross River State, Calabar, Nigeria.

\subsection{Field Investigation}

A trip was taken to the university of Calabar fish farm to ascertain the availability of African catfish (Clarias gariepinus) sub adults. After confirming the availability, the desired quantity was booked for. Similarly, the chosen toxicants were sort for in the various shops.

\subsubsection{Collection and transportation of the study fish}

A total of 600 C. gariepinus sub adults with a mean weight of $8.5 \pm 0.2 \mathrm{~g}$ were purchased from the University of Calabar fish farm. Samples were carefully collected and transferred into a plastic container and transported to the Faculty of Oceanography, University of Calabar, Cross River State, Nigeria. The study fishes were transported to the laboratory in transparent plastic containers by car [45] to the laboratory which is about five minutes drive from the fish farm.

\subsubsection{Laboratory studies}

A whole day was used in arranging the laboratory. Unwanted and obstructive materials were removed and the needed aquaria thoroughly washed and dried.

\subsection{Acclimation of Study Specimens}

The sub adult fish were transferred into a laboratory aquarium (80 × $\left.30 \times 30 \mathrm{~cm}^{3}\right)$ and allowed to acclimatize in this holding tank in the laboratory condition for one weeks at a temperature $30.02 \pm 0.09{ }^{\circ} \mathrm{C}$ and a $\mathrm{pH}$ of 8 , the sub adults were fed once daily with commercial feed (Copen's) at $5 \%$ of their body weight. The unconsumed feeds and faeces were removed from the holding tank and the water in the tank was changed every 24 hours as recommended [46].

\subsection{Pollutants Used for Experiments}

The pollutants selected for the experiment is the Nittol Detergent.

\subsection{Stocking of the Test Fish}

Ten (10) sub adults were carefully were introduced to each of the plastic aquaria containing the measured toxicant and another ten (10) introduced to the control aquaria (plate 5) using a hand sieve, [47]. This procedure was repeated for all the experiments.

\subsection{Range Finding Tests}

Series of range finding tests were conducted using the toxicants and the sub-adult fish to determine the concentration boundaries before the actual experiment. 


\subsection{Toxicity Experiments with Detergent}

The experiment was carried out in triplicates of four treatments i.e. $0.00 \mathrm{~g} / \mathrm{L}$ (control), $1.0 \mathrm{~g} / \mathrm{L}, 2.0$ $\mathrm{g} / \mathrm{L}$ and $3.0 \mathrm{~g} / \mathrm{L}$ and $4.0 \mathrm{~g} / \mathrm{L}$. Ten (10) sub adults of $C$. gariepinus were stocked in each of the four glass aquaria $\left(25 \times 15.5 \times 15.5 \mathrm{~cm}^{3}\right)$ in triplicates for the experiment. The experiment was monitored periodically; observation and responses were taken at intervals of $24,48,72$ and 96 hour respectively.

\subsection{Histopathology of the Gills, Liver and Intestines of the Fish}

After the 96 hours exposure to toxicants, the gills, liver and intestines of the test fish and control were removed by dissection and fixed in separate containers containing $10 \%$ phosphate buffered formalin (PBF). Samples were allowed to fix for at least 48 hours before they were subjected to manual tissue processing.

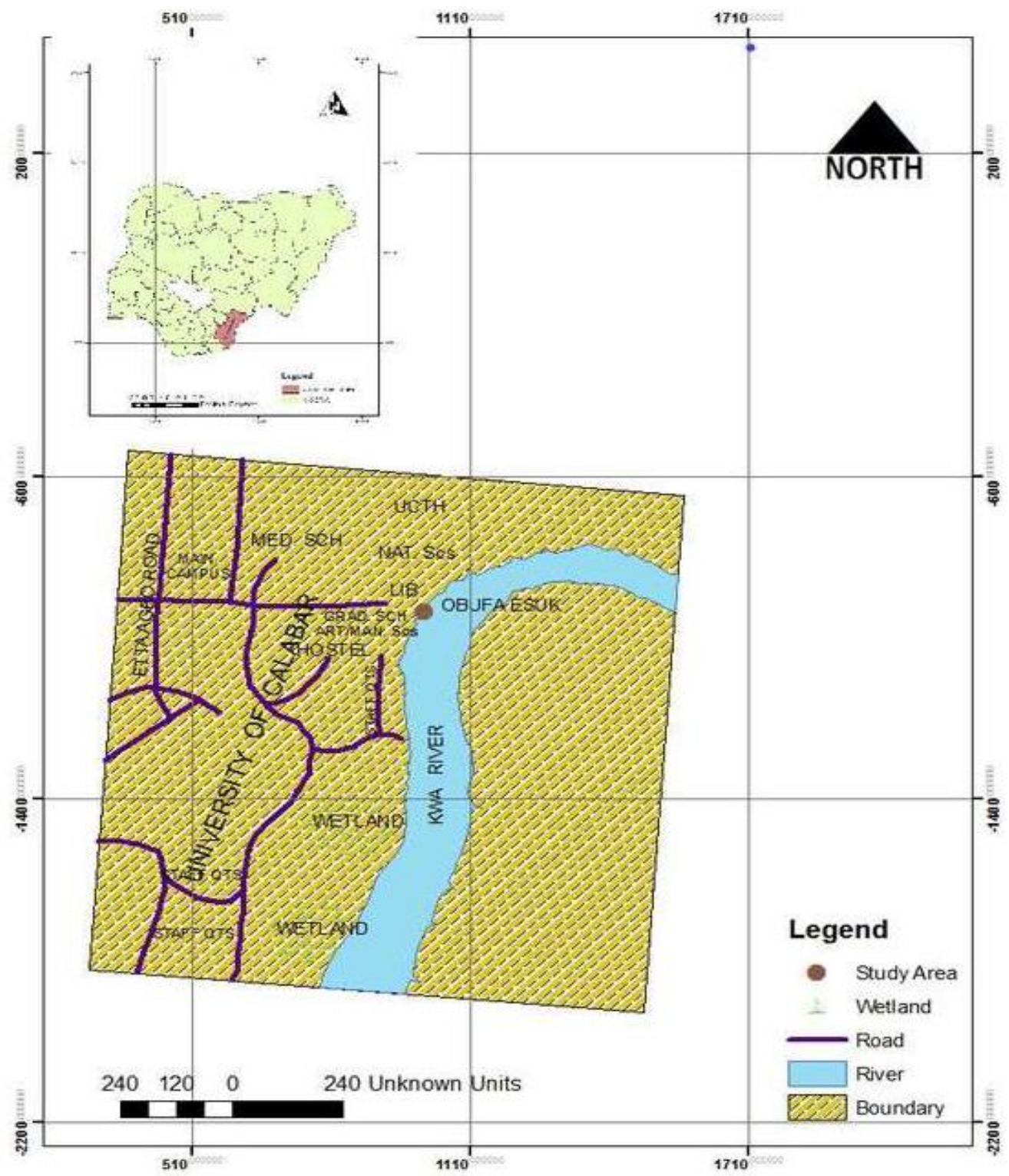

Fig. 1. Map of the University of Calabar showing the fish farm 
Samples were washed thoroughly in water to remove excess fixatives. They were dehydrated through graded series of alcohol, processed into wax, sectioned with a rotary microtome, mounted on glass slides, de-waxed and stained with hematoxylin and eosin stain for microscopic examination at magnification X10.

\subsection{Statistical Analysis}

Data obtained were analyzed using analysis of variances (ANOVA) for significant difference $(p<0.05)$ at $95 \%$ confidence limit. Significant treatment means were separated using the least significant difference (LSD) test.

\section{RESULTS}

\subsection{Necrosis of Liver Cells of Fish Exposed to Different Concentrations of Nittol Detergent}

Plates 1 and 2 shows various degrees of necrosis of livers cells at 1.0 and $2.0 \mathrm{~g} / \mathrm{l}$ concentration respectively. Plate 3 shows damages to the hepatic cells of the liver at $3.0 \mathrm{~g} / \mathrm{l}$ concentration of Nittol detergent when viewed with electron microscope with $\times 10$ magnification. Plate 4 shows serious necrosis of liver cells at $4.0 \mathrm{~g} / \mathrm{l}$ concentration when viewed with an electron microscope at $\times 10$ magnification. In all, a comparison of Plates 1, 2, 3 and 4 with the control (Plate 5) revealed serious alterations of the liver cells when compared with control.

\subsubsection{Damages to the gill lamellae of fishes exposed to different concentrations of Nittol detergent}

Plates 6 to 10 show damages to gills lamellae of fish exposed to Nittol detergent at $1.0 \mathrm{~g} / \mathrm{l}$ to 4.0 $\mathrm{g} / \mathrm{l}$ concentrations respectively when compared to the control (Plate 6) which has normal distribution of gill lamellae when viewed with an electron microscope at $x 10$ magnification. Plates 7 and 8 showed damages to the gill lamellae at 1.0 and $2.0 \mathrm{~g} / \mathrm{l}$ concentration of Nittol detrergent while Plates 9 and 10 shows fusion and severe fusion of gills lamellae of fish exposed to Nittol detergent at concentration 3.0 and $4.0 \mathrm{~g} / \mathrm{l}$ respectively when view with an electron microscope at $\times 10$ magnification. In all, the effects were severe as the concentration increased.

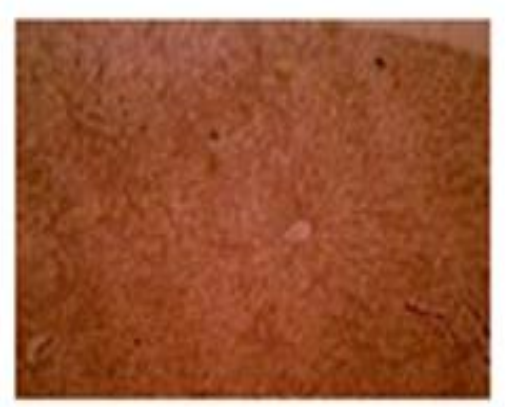

Plate 1. Normal distribution of liver cells

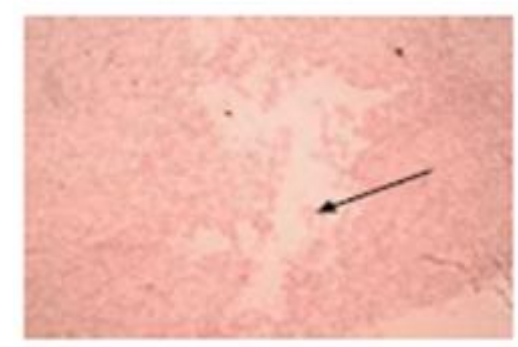

Plate 4. Damages to hepatic cells of the liver at $3.0 \mathrm{~g} / \mathrm{l}$ conc. of Nittol detergent (x 10)

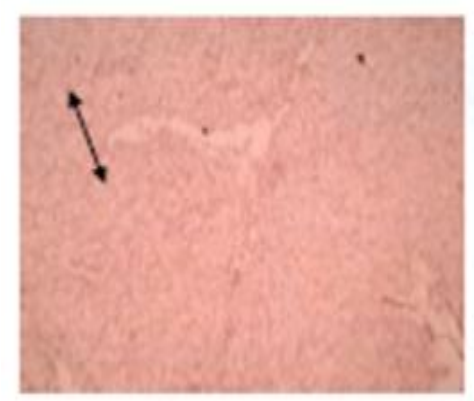

Plate 2. Necrotic cells of liver at $1.0 \mathrm{~g} / \mathrm{l}$ conc.

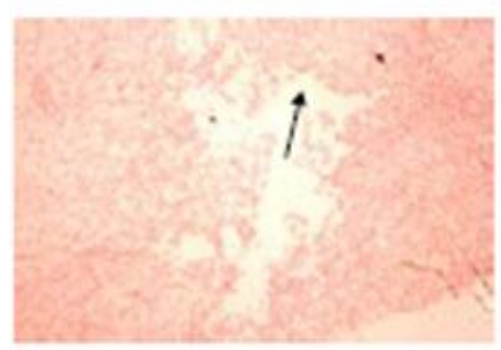

Plate 5. Severe necrosis of liver cells at $4.0 \mathrm{~g} / \mathrm{l}$ conc. of Nittol detergent

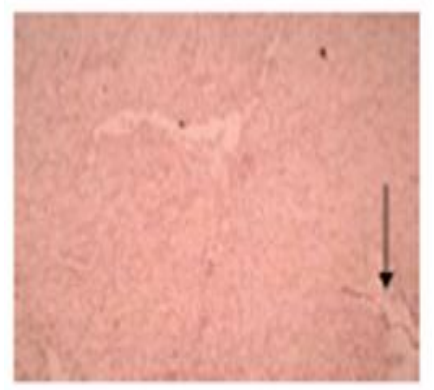

Plate 3. Necrotic cells of the liver at $2.0 \mathrm{~g} / \mathrm{l}$ conc. 


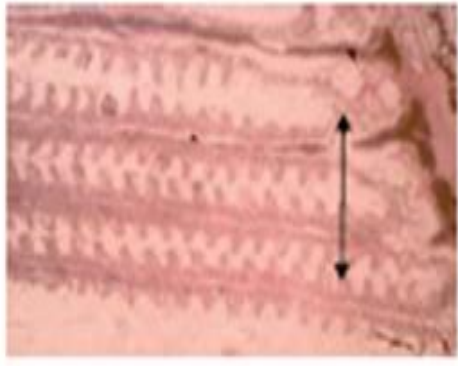

Plate 6. Normal distribution of gill lamellae in control $(x$ 10)

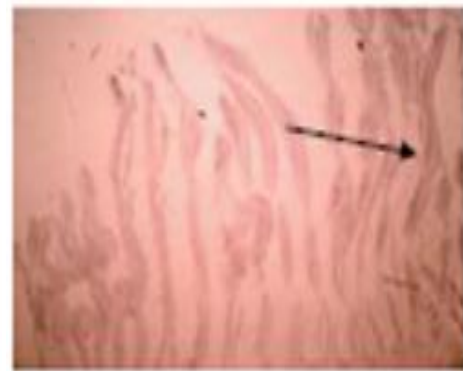

Plate 7. Damage to gill lamellae of fish Expose to 1.0 g/l of Nittol detergent

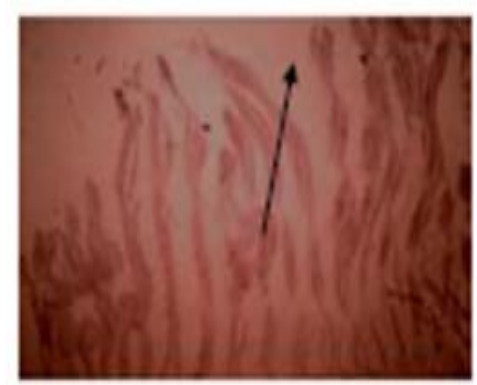

Plate 8. Damage to gill lamellae of fish exposed to 3.0 $\mathrm{g} / \mathrm{l}$ of Nittol detergent

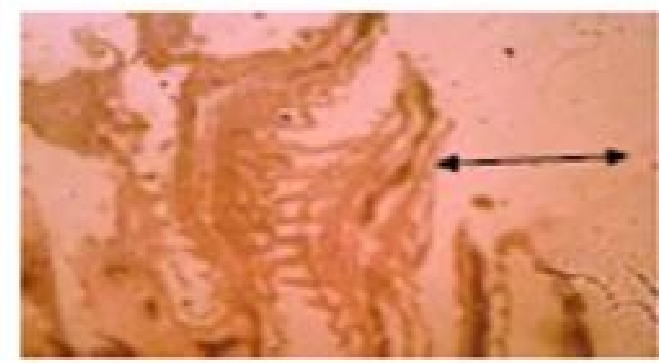

Plate 9. Fusions of the gill lamellae of fish exposed to $3.0 \mathrm{~g} / \mathrm{l}$ of Nittol detergent (x 10)

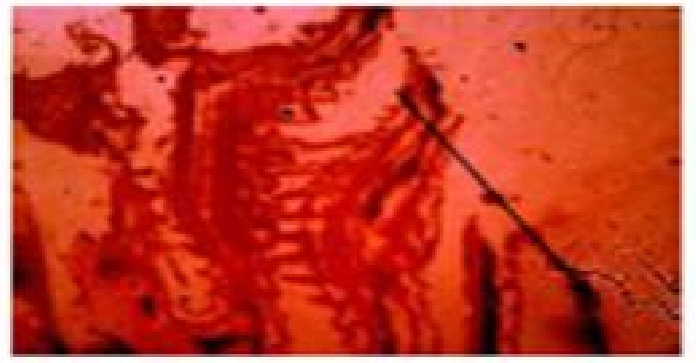

Plate 10. Severe fusions of the gill lamellae of fish exposed to $4.0 \mathrm{~g} / \mathrm{l}$ of Nittol detergent (x 10)

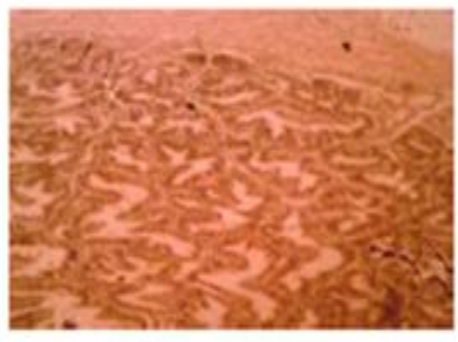

Plate 11. Normal intestine in the control (x 10)

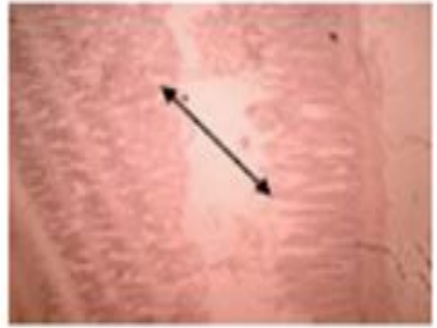

Plate 12. Damage to the intestine of fish exposed to $1.0 \mathrm{~g} / \mathrm{l}$ of Nittol detergent

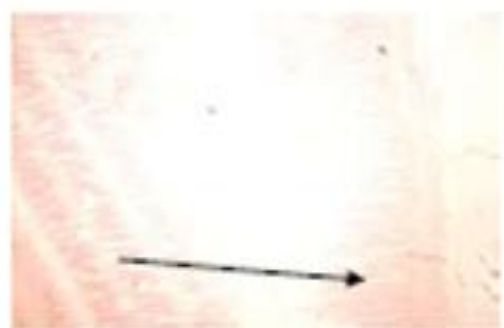

Plate 13. Damage to the intestine of fish exposed to $2.0 \mathrm{~g} / \mathrm{l}$ of Nittol detergent

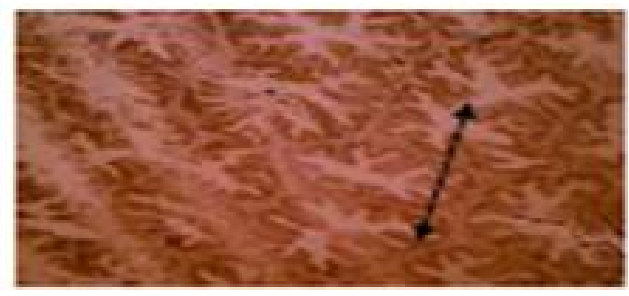

Plate 14. Damage to the intestinal mucosa cells of the intestine of fish exposed to $3.0 \mathrm{~g} / \mathrm{l}$ of Nittol detergent

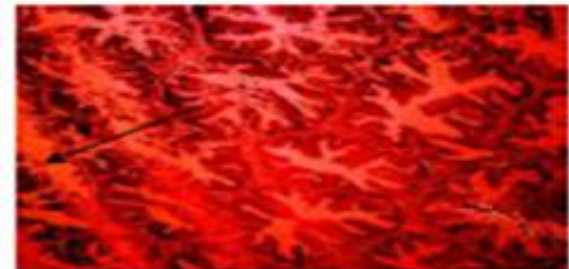

Plate 15. Severe damage to the intestinal mucosa cells of the intestine of fish exposed to $4.0 \mathrm{~g} / \mathrm{l}$ of Nittol detergent (x 10) 
3.1.2 Damages to the intestines and intestinal epithelial cells of fish exposed to different concentrations of Nittol detergents

Plates 12 to 15 showed different degrees of damages to the intestinal epithelial cells at concentration of 1.0 to $4.0 \mathrm{~g} / \mathrm{l}$ respectively when viewed with an electron microscope at $\times 10$ magnification. Plates 12 and 13 revealed damages to the intestines of the fishes exposed to 1.0 and $2.0 \mathrm{~g} / \mathrm{l}$ of the Nittol detergent while Plates 14 and 15 revealed damages and serious damages to the intestinal mucosa cells of the test fish respectively. The effects increased with increase in concentration.

\section{DISCUSSION}

Toxicity of Nittol detergent on the histopathology of the African catfish (C. gariepinus) sub adult was investigated. The experiment was conducted in triplicates of four treatments. Behavioral changes in fish exposed to different concentration of Nittol detergent ranged from erratic swimming, moribund movement, jumping and lack of balance. Similar changes were not observed in the control throughout the experiment. This observation is similar to that of [48]. Nittol detergent is composed of linear Alkyl Benzene Sulphonate (LABS), sodium tripolyphosphate (STPP), sodium carbonate, sodium sulphate, sodium perborate and sodium silicate (perfume) as active ingredients. The ability of these chemicals to cause behavioral changes in $\mathrm{C}$. gariepinus has been reported by $[49,50]$. The fish were exposed to concentrations $1.0 \mathrm{~g} / \mathrm{L}, 2.0 \mathrm{~g} / \mathrm{L}, 3.0 \mathrm{~g} / \mathrm{L}$ and $4.0 \mathrm{~g} / \mathrm{L}$. At $1.0 \mathrm{~g} / \mathrm{l}$ concentration, the mean mortality was $80 \%$ with an initial erratic swimming. It was observed that mean mortality increased drastically with increase in concentration of the pollutant (Nittol). At concentration $3.0 \mathrm{~g} / \mathrm{L}$, total mortality was observed within 72 hours of exposure preceding moribund swimming while total mortality was observed in $4.0 \mathrm{~g} / \mathrm{L}$. The concentration at which $50 \%$ of the experimental fish were killed (LC50) was $0.9 \mathrm{~g} / \mathrm{L}$. Results from statistical analysis indicated that mortality varied significantly with concentrations as higher values recorded higher mortalities. However, mean values showed highest mortality $(74 \%)$ with Nittol detergent.

A bar chart of concentration against cumulative fish mortality exposed to Nittol detergent at timely intervals of $24 \mathrm{~h}, 48 \mathrm{~h}, 72 \mathrm{~h}$ and $96 \mathrm{hr}$ revealed that mortality increased as concentration increased. Total mortality of exposed fish was recorded mainly at $48 \mathrm{hr}$ and $96 \mathrm{hr}$ exposure.

Histopathology of the liver of fish exposed to Nittol after 96 hrs revealed severe damage and necrosis of the liver cells when compared with the control which had a normal distribution of hepatic cells [51] and [52]. Similarly, results from histopathology of the gills of the exposed fish to Nittol detergent revealed fusion and damages to gills lamellae when compared with the control which has normal distribution of the gills lamellae. Severe changes in the epithelia of the gill arch were also observed. This finding corroborates with that of [53] and [54]. Findings from histopathology of the intestine revealed severe damages to the intestinal [55] walls and mucosa when compared with the control fish which had a normal appearance as shown in Plates 14 \& 15 . This finding agrees with the earlier reports $[56,57,58]$.

\section{CONCLUSION}

Histopathology of the liver of the fish exposed to Nittol Detergent revealed severe necrosis of the liver cells when viewed with a motic electron microscope at $\times 10$ magnification. Images from the control showed normal distribution of hepatic cells. Images from the histopathology of the gills revealed severe damages to the gill lamellae by the Nittol detergent whereas the control showed a normal distribution of gills lamellae. And in the same vein, histopathology result on the effect of Nittol Detergent on the intestine of the exposed fish revealed chronic damages to the intestinal mucosa when viewed with motic electron microscope at $x 10$ magnification. In all, a two way Analysis of variance on effect of Nittol detergent toxicant with different concentrations on histopathology of the catfishes at the end of $96 \mathrm{hr}$ bioassay showed significantly different at $\mathrm{P}<0.05$ among the various concentrations studied.

\section{DISCLAIMER}

The products used for this research are commonly and predominantly use products in our area of research and country. There is absolutely no conflict of interest between the authors and producers of the products because we do not intend to use these products as an avenue for any litigation but for the advancement of knowledge. Also, the research was not funded by the producing company rather it was funded by personal efforts of the authors. 


\section{COMPETING INTERESTS}

Authors have declared that no competing interests exist.

\section{REFERENCES}

1. Dambo. Effects of exposing aquatic organisms to crude and refined water soluble oils. Tropical Journal of Zoology. 1999;19:213-219.

2. Ogundiran MA, Fawole OO, Adewoye SO, Ayandiran TA. Pathologic lesions in the gills of Claria gariepinus exposed to sublethal consecrations of soaps and detergent effluent. Journal on Cell and Animal Biology. 2009;3(5):078-082.

3. Abbas $\mathrm{HHH}$, Mahmood HM. The toxicological effect of water pollution on the Nile Tilapia fish (Oreochromis niloticus and Clarias gariepinus) exposed to mixtures of copper and salts. Egyptian Journal of Basic \& Applied Physiology. 2003;3:89106.

4. Ivon, Ndome. Comparative effects of detergents and liquiod soaps on the African catfish (Clarias gariepinus) fingerlings in Calabar, Nigeria. Asian Journal of Biology. 2016;2(4):12-19.

5. Esenowo IK, Ugwumba DA. Growth response of catfish (Clarias gariepinus) exposed to water solube fraction of detergent and diesel oil. Environment Research Journal. 2010;4(4):298-301.

6. Adewoye, Lateef A. Evaluation of the microbiological characteristics of Oyun River-A polluted river in North-central. Pollution Research. 2004;23(14):587591.

7. Adewoye SO, Fawole OO, Owolabi OD, Omotosho JS. Toxicity of cassava wastewater effluents to African catfish: Clarias gariepinus. Ethiopian Journal of Science. 2005;28(7):189-194.

8. Adham KG, Hamed SS, Ibrahim HM, Saleh RA. Impaired functions of Nile Tilapia, Oreochromis niloticus from polluted waters. Ada Hydmchemical et Hydrobiological; 2002.

9. Aguiwo JN. The toxic effects of cymbush pesticides on growth and survival of African catfish, Clarias gariepinus (Bchell, 1822). Journal of Aquatic Science. 2002;77(2):81-84.

10. Udeaja O, Goodness. Effect of petroleum by products (kerosene and fuel) on the hematology of African catfish
(Claria gariepinus). Th Environmentalist. 2016;2(15):25-36.

11. Akhtar $\mathrm{MH}$. The deposition of $\mathrm{I4C}$ agrochemical residues in plants and animals tissue when consumed by animals. In T. Green Halgh and T. R. Roberts (Eds.), Pesticide Science and Biotechnology. Ottawa: Proceedings Chemistry. 1986;10-15.

12. Anastacio PM, Holten-Lutzhoft HC, Hailing-Sorensen B, Marques JC. Surfactant (Genapol OX-80), toxicity to Selenastrum capricornulum. Chemosphere. 2000;40:835-838.

13. Anderson T, Forlin L, Hardig J, Larsson A. Physiological disturbances in fish living in coastal water polluted with bleached kraft pulp mill effluents. Canadian Journal of Fisheries Aquatic Science. 1988;45:15251536.

14. Bucher P, Hofer R. The effects of treated domestics' sewage on three organs (gills, kidney, liver) of brown trout (Salmo irutta). Water Research. 1994;27:255-26.

15. Antonio FF, Jorge VFC, Sofia GS, Sandra MM, Joao C, Pedro M, Antonio FF. Histopathological changes in liver and gills epithelium of Nile tilapia, Oreochromis niloticus, exposed to waterborne copper. Pesq. Vet. Bras. Marco. 2007;27(3):103109.

16. Avoajah DA, Oti EE. Effect of sub-lethal concentration of some pesticides on the growth and survival of the fingerlings of the African freshwater catfish: Heteroclarias (Hybrid fingerlings). Nigeria Journal of Biotechnology. 1997;8:40-45.

17. George RO. Acute toxicity effects of Quo Iboe Crude on the gills of Clarias gariepinus juveniles. Asian Journal of Biology. 2012;1(3):34-40.

18. Ayoola SO. Histopathological effects of glyphosate on Juvenile African catfish (Clarias gariepinus). Ameri-Surasian Journal of Agricultural and Environmental Science. 2008;4(3):362-367.

19. Adewoye SO, Favwole OO. Acute toxity of soap and detergent effluent to fresh water. Clarias garienpinus fingerlings. African J. Sc. 2002;20(5):22-35. In Press

20. Capkins, et al. Study on the sub chronic toxicity of composite inorganic fertilizers such as ammonium sulfate on the skin, liver, gills, pancrease, kidney of Juvenile Rainbow trout fish (Onchorhyn chusmykiss). Tropical Journal of Zoology. 2009;19:180-188. 
21. Adewoye SO, Fawole OO, Owolabi OD, Omotosho JS. Toxicity of cassava wastewater effluents to African catfish (Claria gariepinus). Ethopian Journal of Science. 2005;28(7):189-194.

22. Adham KO, Hamed S, Ibrahim HM, Saleh RA. Impacted functions of Nile Tilapia, Orechromis niloticus from pulluted waters. Acta Hydrochemical et Hydrobiological. Indian Journal of Quaculture. 2002;16(2): 77-80.

23. Isyaku B, Solomon JR. Effects of detergents and the growth of the African catfish (Clarias gariepinus). Tropical Journal of Zoology. 2016;19:198-204.

24. Aghoghovwia OA. Toxicity of detergent to the aquatic environment. First Edition, Nixon Publishers. 2015;12-13.

25. Aguiwo JN. The toxic effects of cymbush pesticides on growth and survival of African catfish, Claria gariepinus (Behell 1822). Journal of Aquatic Science. 2002;17(2):81-84.

26. Andem $A B$, Odey $C O$, Esenowo Ime, Inyang Inimfon. Ecological approach of plankton responses to water quality variables of a tropical River, South-Eastern Nigeria: A bioindicator base of community assessment of Idundu River. Asian Journal of Fisheries and Aquaculture. 2019;3(1):117.

27. Byne P, Speare D, Ferguson HW. Effects of cationic detergents on the gills and blood chemistry of rainbow traut. Salmo Gaurdner. 1989;6:185-196.

28. Canli M, Kargin F. A comparative study on heavy metals $(\mathrm{Cu}, \mathrm{Cr}$. $\mathrm{Pb}$ and $\mathrm{Ni})$ accumulates in the tissue of Carp. Cyprinus carpio and Nile fish. Tilapia niloticus. Tropical Journal of Zoology. 1995;19:165-171.

29. Boughlenger. David 1935 Turgel, 1983 and Hogedoorn, 1980. A Textbook on Characterization of the African Catfish. 1911;25-36.

30. Ekanem, Oscar. Effects of detergents on the behavioural responses of Clarias gariepnus sub adult in Calabar, Nigeria. Asian Journal of Fisheries and Aquaculture. 2004;2(4):23-26.

31. Abel PD. Toxicity of synthetic detergents to fish and aquatic invertebrates. 2006;6(3): 279-298.

32. Adams SM, Shephard KL, Greeley MS Jr., Jimenez BD, Ryon MG, Shugart LR, McCarthy JF. The use of bioindicators for assessing the effects of pollutant stress on fish. Marine Environmental Research. 1989;28:459-464.

33. Adewaye. Comparative study on the behavioural responses of Clarias gariepinus fingerlings on exposure to soaps and detergents effluents. 2010;1:8995.

34. Ekanem AP, Ekpo AL. Effects of commerical detergent on the juveniles of Heterbranchus longifills (Curvier and Valiennees). African Journal of Environmental Pollution and Health. 2006;6(1):18-23.

35. Ekanem AP. Anatomy and physiology of the African catfish (Clarias gariepinus) adults. African Journal of Marine Sciences. 2012;8(1):10-23.

36. Environmental Protection Agency. Chemical limits and standards in the aquatic ecosystem. 2011;45-60.

37. Ewa-Oboho O, Amu. Effects of crude oil extracts on early stages of African catfish Heterobranchus longifilis (VAL) reared under controlled condition. Global Journal on Environmental Sciences. 2009;8(2):3041.

38. Farkas A, Salanki J, Speeziar. Relation between growth and the heavy metals concentration in organs of bream, Abramis brama L., populating late Blaton. Archive of Environmental Contaminants and Toxicology. 2007;43(2):236-243.

39. Francis EA, Ita-Ewa Oboho, Paul J. Udo, Ekaete F. Asuquo. Fish species used as biomakers for heavy metals and hydrocarbon contamination for Cross River State, Nigeria. Environmentalist. 1989;8(2): 30-41.

40. Geetanjali, Choudhavy, Iha. Influence of household detergents on some serum biochemical parameters of fresh water fish, Channa punctata. Asian Journal of Biotechnology. 2013;21(3):121123.

41. Govind PO. Effects of linear alkyl benzene sulfonate on the gills structure of the African catfish (Clarias gariepinus). Environment Research Journal. 2014;4(4): 288-301.

42. Health, Benneth. Hematological and histopathological changes of $C$. gariepinus adults exposed to petroleum product. Journal for Environment and Toxicology. 1990;5(4):20-25.

43. Holzloenher. A textbook on wetlands and coastal zones in Calabar, First Edition. 2002;40-45. 
44. Lenntech. Bulletins detergent occuring in fresh water. Rotterdamsewg: Lenntech BV, 123. 2012;6.

45. Morah FN. Advanced organic chemistry, $3^{\text {rd }}$ Edition. 2012;158.

46. National Population Commission. Statistical update on the Nigerian population in Nigeria, 2016 Edition. 2005;20:12-13.

47. Ndome C, Mowang DA, Ayibaerai TT. Comparative acute toxicity of local detergents (Omo and Ariel) on fingerlings of the Clarias gariepinus, Heterbranchus longifilis hybrid. AACL Bioflux. 2013;6(4): 413-420.

48. Ogundiran MA, Fawole OO, Adewoye SO. Effects of soap and detergent effluents on the haematological profiles of Clarias gariepinus. Science Focus. 2007;12(1):8488.

49. Omoregie F, Ufodike FBC, Keke IR. Tissues chemistry of $O$. niloticus exposed to sub lethal concentration of gammalin 20 and actellic 251EC. Journal of Aquatic Science. 1990;5:33-36.

50. Preeti B, Sexena M. Evaluation of lethal concentration of fertilizer (NPK) to fresh water fish, Mystus vitatus. River State Environmental Protection Agency, 1992. Animal Environment Reports; 2016.

51. Abdel-Moneim AM. Froese (2014). Behaviour, habitat and characteristics of the African catfish (Clarias gariepinus). $2^{\text {nd }}$ Edition. 2005;3-5.
52. Abel PD. Toxicity of synthetic detergents to fish and aquatic invertebrates. 2006;6(3): 279-298.

53. Ogundele O, Ihuahi JA, Omojowo FS, Bitrus $P$. Toxicity of linear alkybenene sulphonate (LAS) detergent, to Clarias gariepinus fingerlings. In $19^{\text {th }}$ Annual Conference of the Fisheries Society of Nigeria (FISON), 29th Nov. 03 Dec. 2004, Ilorin, Nigeria. 2005;271-276.

54. Ogundiran MA, Fawole GO, Adewoye SO, Ayandiran TA. Toxicological impact of detergent efluent on juvenile of African catfish (Claria gariepinus) (Bushell 1822). Agriculture and Biology Journal of North America. 2010;1(3):330-342.

55. Adams SM, Shephard KL, Greeley MS Jr., Jimenez BD, Ryon MG, Shugart LR, McCarth JF. The use of bioindicators for assessing the effects of pollutant stress on fish. Marine Environmental Research. 1989;28:459-464.

56. Adewaye AO. Comparative study on the behavioural responses of Clarias gariepinus fingerlings on exposure to soaps and detergent effluents. 2010;1:8995.

57. Adewoye, Lateef. Evaluation of the microbial characteristics of the Oyun RiverA polluted river in North-Central Nigeria. Pollution Research. 2004;23(14):587-591.

58. Sangeetha DF. Acute toxicity of ammonium sulphate and composite fertilizer NKP 15:15:15 on the African catfish fingerlings; 2011.

(c) 2020 Ivon et al.; This is an Open Access article distributed under the terms of the Creative Commons Attribution License (http://creativecommons.org/licenses/by/4.0), which permits unrestricted use, distribution, and reproduction in any medium, provided the original work is properly cited.

Peer-review history:

The peer review history for this paper can be accessed here: http://www.sdiarticle4.com/review-history/55171 